diplomas a mere nullity, and draw from your funds to recruit the empty treasury of some college of physicians. The public will gain no advantage, nor will you, the graduates of Edinburgh;- - who then will? - the impoverished College of Physicians, who, under their new charter, will secure the privilege of unjustly putting their hands into your pockets.

It is intended to send hence a petition to Parliament, or a memorial to Sir James Graham, or both, claiming a continuance of our present rights and privileges, without suffering the exaction of any other fee than that for registration; and it is to be hoped that many similar petitions will be forwarded by you, gentlemen, to secure yourselves from the evil that will ensue from any such retrospective operation of the new Medical Bill, or of new Charters, as there is reason to believe is intended.

My apology for intruding myself thus publicly on your notice is, simply, that your interests are in jeopardy, and I therefore hope to secure your indulgence.-I am, gentlemen,

Your most obedient servant,

P. Ballantine Fergusson, M.D.

A Graduate of the University of Edinburgh of 1819. QUERIES TO SIR JAMES GRAHAM.

I. Will the graduates in medicine of the University of Edinburgh, now in possession of their diploma, simply as such, on producing them to the Council of Health, be allowed to register as legal physicians?

2. Or will it also be necessary for such graduates to become fellows, associates, or licentiates, of some college of physicians, or of that college of physicians of that division of the kingdom in Which they reside, and if such connexion with a college of physicians is obligatory on them, will any fee of admission be demanded, and of what amount?

14, Rivers-street, Bath, 18 March, 1845.

\section{REGISTRATION UNDER SIR JAMES GRAHAM'S NEW MEDICAL BILL.}

To the Editor of THB LANCET.

SrR,--May I hope that you will give early publicity in the pages of your journal, to the following letter, which I addressed to Sir James Graham on the above subject, and also to the answer which I received to it?- Your obedient servant,

Charles Crapdock.

To the Right Hon. Sir James Graham, Bart., Secretary of State for the Home Department.

Sir,-As considerable doubt exists in the minds of medical men, as to the interpretation of Clauses 13 and 32 of the "Bill for regulating the Practice of Physic and Surgery," I should esteem it a favour if you would oblige me with answers to the following questions:-1st. Would members of the College of Surgeons, who hold also the licence of the A pothecaries' Company, be allowed to register as surgeons and also as licentiates in medicine; and if so, would the double fee be required for such registration?-2ndly. Would individuals who hold the diploma of the College of Surgeons only, and who have passed no examination whatever in medicine, be entitled to register as licentiates in medicine and surgery, and to recover for attendance on medical as well as on surgical cases? and, on the other hand, would individuals who hold only the licence from the Apothecaries' Society, and there are very many such practising as general practitioners, be entitled to register as licentiates in medicine and surgery, and to recover for attendance on surgical as well as on medical cases?

As meetings of the profession are about to take place, I think it very desirable that your opinion on these points should be ascertained.

I have the honour to remain, Sir,

Your obedient humble servant,

Charles Craddock,

March 10, 1845.

Whitehall, March 17, 1845.

Sir,-I am directed by Secretary Sir James Graham to acknowledge the receipt of your letter of the 10th instant, upon the subject of the Medical Practice Regulation Bill, and to acquaint you, in answer to the first query in your letter, that the Bill does not contemplate double registration, nor would anything be gained by it.

Members of the College of Surgeons will be entitled to register as surgeons, and being so registered, may practise as general practitioners if they please.

With respect to your second query, it is believed the number of those who have passed the Surgeons' College only, and yet practise generally, is not great. They will be entitled to register as surgeons, and to practise generally under the Bill.
Those who have the Apothecaries' licence only, will be entitled to register as licentiates, and to practise generally in surgery as well as medicine.

There is some inconvenience in this course, but not so great as would follow the opposite course.

Hereafter the Bill makes provision for complete examination in both medicine and surgery.

I am, Sir, your obedient servant,

To Charles Craddock, Esq.,

S. M. Perrhlips.

6, Chapel-piace, Cavendish-square.

\section{CORRESPONDENTS.}

H. M.S. F.-If the University of St. Andrews can confer on its graduates the legal right to practise as physicians in any part of Scotland, however small, they will be able to register as physicians. It is not stated in the Bill whether the members of the Colleges of Surgeons of Edinburgh and Ireland, who undergo a general examination, will be admitted to register as licentiates in medicine and surgery. It would depend on the council to register them or not as surgeons. The Bill in its present state is very incomplete in these respects.

Londinensis. - All physicians, being members of British universities, which can give them a right to practise in any part of the kingdom, will be able to register as physicians. Londinensis will find, in clause 32 , the provisions for the registration of those now in practice.

$P$. S. will be able to register as a licentiate in medicine and surgery, and to retain the word Surgeon on his door.

An Old Subscriber will be able to register as a licentiate in medicine and surgery, and to retain his present appointment.

An Edinburgh Student.-From the wording of clause 32, it would appear that the new Bill would not come into operation until the end of this session of parliament, so that all students who pass their examinations before that period will be able to register under clause 32 .

A General Practitioner.-Foreign graduates who possess no British qualification will, most certainly, not be able to register.

R. $M$. (Cornwall.) - No foreign degree alone will entitle to register, without the licence of a college of physicians, and no foreign degree will entitle to examination before a college, unless obtained by residence. All graduates of British Universities having the power to confer a licence to praetise in any part of the United Kingdom, will be able to register as physicians.

$A$. B.-The present members of the Apothecaries' Company will be able to register as licentiates in medicine and surgery in virtue of their licence. - Licentiates in Medicine and Surgery. Clanse 20 only applies to those who after the passing of the Act undergo the tripartite examination.

A $\nu \theta_{\rho}$. - The card forwarded to us is certainly a novel mode of attempting to get into practice, and anything but creditable to the gentleman who circulates it.

Pater's (!) Son will be able to register as a licentiate in medicine and surgery, and to retain his present title.

Mr. Barrington's note reached us too late to enable us to make the desired alteration.

A Constant Reader (Zeta.)-As a surgeon, or as a licentiate in medicine and surgery.

Inquisitor will be able to register as a surgeon. The Dublin midwifery certificate is not recognised in the Bill.

If a Surgical Student passes his examination at the College of Surgeons previous to the Bill's coming into action, he may, and most likely will, be admitted to register as a surgeon.

T. R.-The Irish Apothecaries' Company is not mentioned in the Bill.

M.D. Edin., and F.R.C.P.E.-It is only the British Universities that can give a licence to practise, somewhere or other, the graduates of which will be able to register as physicians. The graduates of the two bodies mentioned, although not named in the Bill as it now stands, will be most likely allowed to register as licentiates in medicine and surgery.

Senex.-We are not aware whether the University of St. Andrews can give a licence to practise or not. The fellows of the Edinburgh College of Physicians would only become associates of the London College on enrolment.

A Subscriber (Kennington.)-First. A licentiate of the Hall will be able to register as a general practitioner. Second. A member of the College will be able to register as a surgeon. There is no provision for double registration. Third. The registration qualification for poor-law appointments is not mentioned in the Bill.

An Apprentice. - What we stated with respect to the apprenticeship, referred more especially to the old Bill, by which the Apothecaries'Act was repealed. As in the amended Bill that Act is retained, it is evident that the apprenticeship to members of the Apothecaries' Company cannot be said to be destroyed. At the same time, apprenticeship not being recognised or demanded in the Bill, for any grade of the profession, it is evident that it would become a dead letter. Present apprentices will, most likely, have to conform to the regulations of the Bill, on graduating, whatever these regu. lations may be.

A Subscriber.-The suspicion of her having died from neglect ought to have induced the coroner to order a post-mortem examination. 
The emendations of $\boldsymbol{M} . \boldsymbol{D}$. shall be fully considered.

A Subscriber would not be able, with his present qualification, to hold a poor-law appointment. Under the new Bill he would register as a licentiate in medicine and surgery.

Chirurgus (Northleach.)-The coroner was not obliged.

A Constant Subscriber (Heidelberg.) - Not as phssician, but probably as a surgeon. The other question is answered in several other notices.

A Constant Reader is referred to the author of the paper alluded to in his letter. His address is afixed to his communication. We are satisfied that he will afford our correspondent every facility in the solution of his ques. tions, as well as his assistance in the interesting history he proposes to compile.

We have received the letter from Dorchester, expressive of the disapprobation of the general practitioners of that town of the amended Bill, and their intention to prepare petitions against it to present to parliament.

No Fellow.-A. would be able to register as a surgeon, as a licentiate in medicine and surgery, or as both ; $B$. would be able to register as a licentiate in medicine and surgery; and as to D., we do not see how he could register at all.

One in a state of Uneertainty.-As a surgeon, or as a physician. It is not known what the College of Physicians means to do with its extra licentiates.

A Constant Reader.-Those who possess double qualifications will not be sble to register in a double capacity.

A Constant Reader, as a licentiate of the Apothecaries' Company, will register as a licentiate in medicine and surgery, and no doubt, as such, be allowed to occupy a poor-law appointment. The power will rest, however, with the council (clause 28.)

Mr. J. Pearce's paper was duly received, and shall be inserted as soon as possible.

The principle against which Justus inveighs has been considered. We agree with him, that the course pursued in this instance is unjust to those who have completed their medical and surgical education, but we dount whether it will be possible to oppose it with any chance of success None of the public associations appear inclined even to give an opinion on the subject.

$P a *$, a Constant Subscriber.-According to clause 32, University M.B.'s, if legally qualified by their M.B. degree to practise in any part of the kingdom, will be able to register as physicians. It is for those who hold such degrees to ascertain from their respective universities what legal rights have been conferrcd upon them. We should suppose that under the new Bill the Inceptor degree will replace that of M.B.; it will give power to register as licentiate in medicine and surgery. Our correspondent's London degree will enable him to register in the latter capacity.

We are not able to give $M r . H . L-s$ the name and address which he rcquires.

Ar. $B$, Broadhurst's case has been received, and shall be inserted in an early number.

Mr. Meade's paper shall appear very shortly.

We have been requested to insert the following letter :"Synclonus Baluismus of Mason Good.

- SiR,-A most obstinate case of the above disease has resisted for the last two years all treatment, physical and mechanical, that extensire experience and careful consideration could suggest. Will, therefore, some of your numerous readers favour me with any remedies which they have found useful either to mitigate or cure this distressing complaint ?

"Yonr insertion of the above letter in your widely-circulated Journal, will oblige, Sir, your obedient servant,

Wilgiay Patteson, M.R.C.S

"Cecil-square, Margate, March 10, 1845."

A ccrrespondent writes as follows, in reference to the paper of $\boldsymbol{Y} . Z$., published in a late number of THE LANCET:-_" Your correspondent has merely added to the old and well-known nitrate of silver injection, a syringe of a peculiar make, which he applies bimself, thereby giving to the minds of his patients an air of empiricism in his treatment, but the advantages of which I cannot see over the common ivory or glass instruments. The antiphlogistic plan, he speaks of, is had recourse to by every well-informed medical man, when the inflammatory symptoms are high. Balsam copaiba merely robs the urine of its mucus, being possessed, I believe, of very little, if any, other virtue, nature doing a great deal towards the cure when not obstructed by intemperance or other means. I will conclude by giving a word of advice to your correspondent-namely, to be very cautious in the use of injections, even though the inflammation may be fast subsiding, and it not a first time for the patient to be suffering under gonorrhoea, should there be much discharge; otherwise the very prudent precaution of wearing a suspensory bandage will not at all times be sufficient to prevent orchitis.

$$
\text { "E. G." }
$$

The questions sent to us by the various correspondents, which are unnoticed this week, will be answered in the next LANCET.

Communications have been received from Chirurgus-A Subscriber-No Fellow-Mr. Charles Clough-Mr. Hyde Clarke-Y. Y. Y.-Mr. F. Bastone -Dr. Brown (Boston)-Mr. W. Curtis-Dr. J. S. Campbell-A Constant

Reader-D. E. L.-M.D. Edin.-Mr. R. Eager-J. T. P.-Beta-VindexMr. Champneys-D. M. D.-Mr. J. Symonds-Mr. W. C. Radley-Dr. R. MacDonnel-A Cosmopolite.
DR. PEREIRA'S NEW WORK ON FOOD.

Just published, One Volume, 8vo, $16 \mathrm{~s}$.

TREATISE on FOOD and DIET: with Observations A on the Dietetical Regimen suited for Disordered States of the
Digestive Organs. By JoN. PEREIRA, M.D., F.R.S. \& L.S., \&c. \&c., Digestive Organs. By Jon. PEREIRA, M,
Auth $\rightarrow$ r of "Elements of Materia Medica."

London: Longman, Brown, Green, and Longmans.

This day is published, price 1s.,

CASE OF CASARIAN OPERATION, accompanied with Pathological Remarks on Puerperal Metritis, or Acute Inflamwith Pathological Remarks on Puerperal Metritis, or Acute InflamMember of the Royal Colleges of Physieians and Surgeons in London.

London: Longman, Brown, Green, and Longmans.

NEW MEDICAL BILL.

This day is published, 8vo., price is.

THHE APOTHECARIES' SOCIETY'S 2nd ADDRESS to General Practitioners on the New Medica! Bill, as contrasted with the Bill of last session.

\author{
S. Highley, 32, Fleet-street.
}

MR. TRAVERS, NEW WORK.

Just published, 8vo, price $7 \mathrm{~s}$, the

DHYSIOLOGY of INFLAMMATION and the HEALING PROCESS.

BY BENJAMIN TRAVERS, F.R.S.

S. Highley, 32, Fleet.street.

UNIVERSITY OF GIESSEN.

W $\mathrm{W}$, the Undersigned Members of the Medical Faculty of the $\sqrt{\text { University of Giessen, feel ourselves called upon at the present }}$ time to make the following public declaration :-

We never have corferred, and never will confer, the Degree of Medicina Doctor on any one who has not been personally examined by us, excepting upon proof of his being legally entitled to practise medicine in Great Britain Hall, or other licensing and examining body, or of his being in the British Hall, or other licensing and examining
Naval, or Military Medical Service, \&c.

Naval, or Military Medical Service, \&c.
The surest way by which possessors of our Diplomas can prove their The surest way by which possessors of our Diplomas can prove their
authenticity is, by shewing the correspondence which has taken place, directly or indirectly, between themselves and the Dean of our Faculty, to Dr. MACKISZIE, 68, Mortimer-street, London, who will shew this document, with our seal and autograph, to any person interested therein.

We have also placed in charge of Dr. Mackenzie, the Register of our English Graduates in Medicine, up to 1844 inciusive, for further reference, if necessary.

Giessen, 13th March, 1845. Dr. G. F. W. BALSER, Dean,
and the other Professors of the Medical Faculty.

$\mathrm{D}^{\mathrm{n}}$ WATSON'S INHALER for SORE THROAT and COLD on the CHEST is extensively used in the principal Metropolitan Hospitals, and strongly recommended by the most eminent of the Faculty. Hot, Cold, Shower, and Vapour Baths in the greatest variety. James Bord and Son, 78 , Welbeck-street.

GLUTES, 78, STRAND.-Eight-keyed Cocoa Flutes, with f patent head, silver keys, (double springs,) tips, \&c., with rosewood case, cleaner, and instruction book, $5 l$. $5 s$., or German Silver, including the Flute, 78, Strand, London. Flutes repaired and taken in exchange.

EECHES, \&c.-POTTER and HAILEY, Importers of Id Leeches, Herbalists, \&c., 66, Farringdon-market, London, respectfally inform Druggists, Surgeons, and the Medical Profession in general, that they can always be supplied from their Establishment with the fine
POND LEECHES, so universally approved of by their present patrons.

P. and $H$. also invite attention to their stock of English and Foreign Medicinal Herbs, Roots, Seeds, \&c., lists of which will be forwarded, post Medicinal Herbs, Roots, Seeds,
frce, on application as above.

NTORY, TAILOR, DRAPER, and GENERAL OUT-

FITTER, 62, FIEET STREET, (comer of Bouverie-street, with Whom few oan compete, and none can excel, in cut, quality, and price, whom few oan compete, and none can excel, in cut, quality, and price,
solicits the attention of professional gentlemen to the following quotations solicits the a
of prices :-

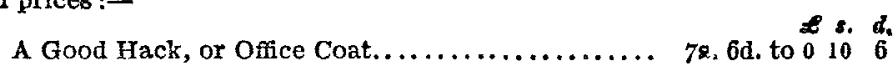

Woollen Shooting, or Morning Coats .................. o 126

Over Coats, in Fine Light Waterproof materials, or Stout

Cloths, suitable to the season.................. o $17 \quad 6$

Stout mill'd cloths $\ldots \ldots \ldots \ldots \ldots \ldots \ldots \ldots \ldots \ldots \ldots .25 s ., 30$ s., 35 .

Prime Cloth Frock, or Dress Coats, in all shades of colours, from 1116

$\Lambda$ Real Good Article, no better need be had ............ \& 20

Extra Fine, for First Dress Circles; no house can better this

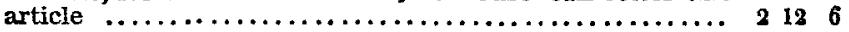

Trousers, in several thousand patterns, 7s. 6d., 10s. 6d.,

IN THI WAISTCOAT DEPARTMENT ALL THE FATTERMS THE BRITISK AND FOREIGN HAREXTS WILL PRODUCE.

*** Observe the Address-

STORY, PROFESSED TAILOR, 62, FLEET STREET. 